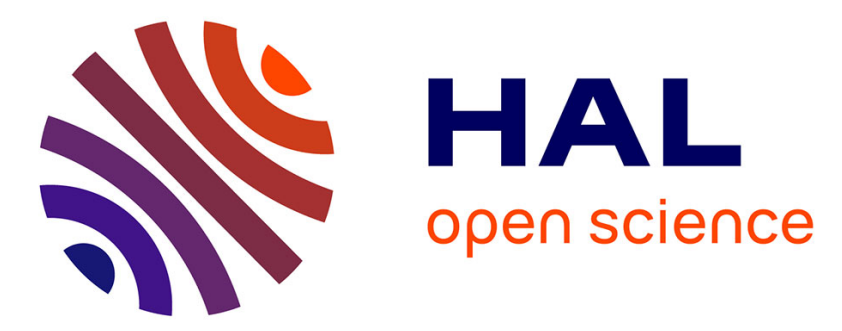

\title{
Soil nutrient dynamics in colonies of the yellow-legged seagull (Larus michahellis) in different biogeographical zones
}

\author{
S. de La Peña-Lastra, Laurence Affre, X.L. Otero
}

\section{- To cite this version:}

S. de La Peña-Lastra, Laurence Affre, X.L. Otero. Soil nutrient dynamics in colonies of the yellowlegged seagull (Larus michahellis) in different biogeographical zones. Geoderma, 2020, 361, pp.114109. 10.1016/j.geoderma.2019.114109 . hal-03174836

\section{HAL Id: hal-03174836 https://hal.science/hal-03174836}

Submitted on 19 Mar 2021

HAL is a multi-disciplinary open access archive for the deposit and dissemination of scientific research documents, whether they are published or not. The documents may come from teaching and research institutions in France or abroad, or from public or private research centers.
L'archive ouverte pluridisciplinaire $\mathbf{H A L}$, est destinée au dépôt et à la diffusion de documents scientifiques de niveau recherche, publiés ou non, émanant des établissements d'enseignement et de recherche français ou étrangers, des laboratoires publics ou privés. 


\title{
Soil nutrient dynamics in colonies of the yellow-legged seagull (Larus michahellis) in different biogeographical zones
}

\author{
S. De la Peña-Lastra ${ }^{a}$ L. Affre ${ }^{\mathrm{b}}$, X.L. Otero ${ }^{\mathrm{a}, *}$ \\ ${ }^{a}$ Departamento de Edafoloxía e Química Agrícola, Facultade de Biología, Universidade de Santiago de Compostela, 15782-Santiago de Compostela and Instituto Cross- \\ Research in Environmental Technologies (i-CRETUS), Spain \\ ${ }^{\mathrm{b}}$ Institut Méditerranéen de la Biodiversité et d'Ecologie Marine et Continentale (IMBE), Univ. Aix Marseille, CNRS, IRD, Univ. Avignon, Av Escadrille N. Niemen, case 421, \\ 13397, Marseille cedex 20, France
}

\section{A R T I C L E I N F O}

Handling Editor: Jan Willem Van Groenigen

\section{Keywords:}

Seabirds

Nitrogen

Phosphorus

Mediterranean and Atlantic climates

Granite

Limestone

\begin{abstract}
A B S T R A C T
Seabirds drastically alter the ecosystems where they establish their colonies. However, previous studies have not considered how colonies of the same species affect their surroundings in different environmental contexts. The main objective of this study was to determine the degree to which environmental factors (particularly climate and lithology) modulate the impact of seabird colonies on soil nutrients. For this purpose, two breeding colonies of the yellow-legged gull were selected: one located in the Atlantic Islands National Park (AINP, Atlantic region) and the other in Calanques National Park (CNP, Mediterranean region). In both parks, samples of soil and excrement were obtained from colonies with different densities of birds and in control zones, without birds, in two different seasons (winter and summer). The samples were analysed to determine the concentrations of $\mathrm{N}$ $\mathrm{NO}_{3}{ }^{-}, \mathrm{N}^{-\mathrm{NH}_{4}}{ }^{+}$, total $\mathrm{P}$ and different geochemical P forms, including bioavailable $\mathrm{P}$. The colony soils were enriched in $\mathrm{N}$ and $\mathrm{P}$ relative to soils from the control zones. However, the annual nutrient dynamics were modulated by the environmental conditions in each park. In winter in $\mathrm{CNP}, \mathrm{NH}_{4}{ }^{+}$concentrations were low and similar to those in the control zones, while the concentrations of $\mathrm{NO}_{3}{ }^{-}$were highest at this time of year. By contrast, in AINP, the annual $\mathrm{N}$ cycling appeared to be less variable, although the $\mathrm{NH}_{4}{ }^{+}$concentrations were lower than in the control zone in winter, while those of $\mathrm{NO}_{3}{ }^{-}$remained high, despite the high rainfall in this season. The concentrations of $\mathrm{P}$ (total and bioavailable) remained high in soils in both parks throughout the year. However, fractionation of the P forms revealed different geochemical behaviour at the two sites. In CNP, calcium phosphate and residual $\mathrm{P}$ were the dominant fractions. In AINP, the $\mathrm{P}$ was distributed more homogeneously between the different fractions, with a slight predominance of the $\mathrm{P}$ associated with Al hydroxides and clays. The findings clearly show alteration of the cycling of both nutrients in both parks, although the impact is modulated by the environmental conditions at each location.
\end{abstract}

\section{Introduction}

The yellow-legged gull Larus michahellis occurs throughout Europe, the Middle East and North Africa. In Europe, the overall population of the species increased slowly until 1980, after which it underwent exponential growth until becoming one of the most abundant seabird species in Mediterranean and Atlantic coastal regions (Barros, 2015; Rizet, 2015; Vidal et al., 1998). However, the numbers have decreased drastically in recent years (Barros, 2015; Galarza, 2015; Rizet, 2015), probably due to closure of urban waste dumps and reductions in fish discards (Oro et al., 1995; Ramos et al., 2009). Previously, the enormous increase in the population had led to some controversy regarding the need to take control measures as the huge numbers of gulls threatened the conservation of habitats and species in several island systems (e.g. Berlengas, Chafarinas and Cíes islands).

Colonies of the yellow-legged gull have previously been studied with the aim of evaluating the effect of the species in shaping ecosystem biodiversity. The findings of different studies have revealed changes in plant composition, vigour of native species and also the appearance of ruderal species on the island cliffs where the colonies are established (Guitián and Guitián, 1989; Vidal et al., 1998a,b; Mouriño and Otero, 2002; García et al., 2002). More recently, different studies have revealed significant changes in various properties of soils and waters and in the concentrations of nutrients $(\mathrm{N}, \mathrm{P}, \mathrm{K})$ and trace elements $(\mathrm{Zn}, \mathrm{Pb}$, $\mathrm{Hg}$ ). The presence of yellow-legged gulls on Chafarinas Islands (North Africa) induced eutrophication, salinization, acidification and nutrient 
imbalances (García et al. 2002, Signa et al. 2013).. De la Peña-Lastra et al. (2018) observed that the presence of yellow legged-gull colonies in the Atlantic Islands National Park (NW Spain) led to the incorporation of oligoelements (e.g. $\mathrm{Cu}, \mathrm{Zn}, \mathrm{Co}$ ) and $\mathrm{P}$ in the colony soils, via inputs of biological materials, mainly excrement and pellets. These researchers also observed that the total concentrations of oligoelements and $\mathrm{P}$ in the soil were related to the density of gulls in each subcolony.

However, the aforementioned and other previous studies (see e.g. Sobey and Kenworthy, 1979, Hogg and Morton, 1983, Lindeboom, 1984) mainly focused on comparisons between soils and water in the colonies and in control zones (without seabirds). To our knowledge, no previous studies have considered or compared the effects of colonies of the same gull species in different environments. The mobility and bioavailability of macro and micronutrients in soil are strongly dependent on climatic conditions and lithology (Sposito. 1989). In the first instance, climate and lithology exert a strong influence on soil composition and properties (i.e. pH, texture, mineralogy, etc). Furthermore, climate parameters (including temperature, hydric and edaphic availability) and $\mathrm{pH}$ regulate essential processes involved in soil nutrient dynamics, such as nitrification, the composition of interstitial water, solubility and partitioning of soil nutrients, especially $\mathrm{P}$ (for more details, see Bonilla and Rodà, 1992, Rutigliano et al., 2009).

Taking all of the above into account, the present study aimed to evaluate how the impact of seabirds on soil nutrient ( $\mathrm{N}$ and $\mathrm{P}$ ) dynamics is modulated by climate and lithology in areas where yellow-legged gull colonies are established. For this purpose, breeding colonies were selected for study in two areas with different climatological and geological characteristics: the Atlantic Islands National Park (AINP) located in the NW Iberian Peninsula, characterised by a wet Atlantic climate and a geological substrate formed by granite, with acid soils; and Calanques National Park (CNP) situated in SW France, characterised by a dry Mediterranean climate and a substrate formed by limestone. Sampling zones with different densities of gull were established in the breeding colonies and in an area without gulls (control zone) in each park. Sampling was performed seasonally to evaluate the effects of seasonal changes on soil nutrient dynamics.

\section{Material and methods}

\subsection{Environmental context}

The study area comprised two zones: the Atlantic Islands National Park (AINP), located on Atlantic side of Iberian Peninsula (NW Iberian Peninsula); and Calanques National Park (CNP) situated on Mediterranean coast of France (SW France): (Fig. 1; Table 1). In AINP, yellow-legged gull colonies on the cliffs in Cíes and Ons islands were selected for study, and a control plot (without gulls) was established on the mainland, on the Cabo Home cliffs (Fig. 1B). In the Mediterranean zone, the gull colonies and the control plot selected for study were located in the Frioul archipelago (Fig. 1C).

\subsubsection{Atlantic Islands National Park (AINP)}

The geological substrate of AINP is constituted by a two-mica granite. The elevation ranges between 10 and $80 \mathrm{~m}$ a.s.l., and the mean precipitation recorded during the study period (from winter 2011 to winter 2013) in the weather station installed at Figueiras cliffs (Cíes Islands) was $1419 \mathrm{~mm}$. More than $80 \%$ of the precipitation was concentrated between September and March $(\sim 1100 \mathrm{~mm}$ ) (Supplementary Fig. 1). The mean annual temperature is $15.3{ }^{\circ} \mathrm{C}$ (ranging from $4{ }^{\circ} \mathrm{C}$ in winter to $34{ }^{\circ} \mathrm{C}$ in summer) (Meteogalicia, 2018).

According to the classification of (Allué, 1966), the area is characterised by a subhumid Mediterranean climate with Atlantic tendency (Vilas et al., 2014). The soils in the gull colonies in AINP and the control zone (Cabo Home) have been analysed in previous studies and are characterized as follows: poorly developed; depth to underlying rock, 15-25 cm; sandy texture (sand fraction $\sim 70 \%)$; slightly acidic $(\mathrm{pH}$
5.1-5.8); high organic C content (11-16\%); and low electrical conductivity (despite the proximity to the sea), ranging between 522 and $771 \mu \mathrm{S} \mathrm{cm} \mathrm{cm}^{-1}$ in the colony soils and $1308 \pm 1319 \mu \mathrm{S} \mathrm{cm}^{-1}$ in the control zone (De La Peña, 2012; Otero et al., 2015; Otero et al., 2016). The soils are classified as Mollic Leptosols (Arenic, Humic) (De La Peña, 2012; WRB, 2014) (Supplementary Table 1).

The cliffs in AINP are partly covered by different plant communities, except in zones of granite outcrops (Fig. 1). In the absence of gulls (i.e. Cabo Home cliffs), Chrithmo-Armerietum pubigerae association occurs on the lowest parts of the cliffs, which are most exposed to wave splash. A community formed by Dauco-Festucetum pruinosae occurs on higher slopes, where the soil is deeper. In Galicia, this community is dominated by the grass Festuca rubra subsp. pruinosa. Finally, the upper part of the slope is occupied by aerohalophilic shrubs, dominated by the endemic gorse Ulex europaeus subsp. latebracteatus (Otero and Pérez Alberti, 2009). However, on the cliffs where the yellow-legged gulls are established, the distribution of the plant communities does not follow any clear pattern, and new communities of halo-ornithcoprophilic character, such as Cochelario danicae-Matricarietum maritimae and Calendulo algarbiensis-Parietaritarietum judaicae, have been described (Guitián and Guitián, 1990).

\subsubsection{Calanques National Park (CNP)}

In CNP, the study was conducted in the Frioul archipelago. The islands in this archipelago are covered by a mosaic of Mediterranean shrubs (e.g. Pistacia lentiscus, Rosmarinus officinalis, Coronilla juncea and Lavatera arborea) and xeric grassland, with a high proportion of bare soil and rocky patches (Vidal et al., 2000). The geological substrate is constituted by limestone $\left(\mathrm{CaCO}_{3}\right)$. The elevation ranges between 3 and $36 \mathrm{~m}$. a.s.l. The climate is arid Mediterranean (semi-arid thermo Mediterranean zone, Médail and Quézel, 1999): the mean annual temperature is $15.2{ }^{\circ} \mathrm{C}$ (Bonnet et al., 1999) with large annual variations (from $-16{ }^{\circ} \mathrm{C}$ in winter to more than $40{ }^{\circ} \mathrm{C}$ in summer), the mean precipitation is around $350 \mathrm{~mm} \mathrm{y}^{-1}$, with more than $80 \%$ occurring between November and April (280 mm) (Fig. S1), mainly as cold rain; there is also period of intense drought in summer and strong winds occur on more than 200 days per year (Douguedroit, 1983).

The soils are less well developed than in AINP and are characterised by being of depth $<10-15 \mathrm{~cm}$ (Rendzic and Lithic Leptosols, WRB, 2014), neutral-alkaline ( $\mathrm{pH}$ 7.5-9), with a high total organic C content (8-21\%), moderate electrical conductivity, with environments ranging from those with a low ionic charge to slightly saline environments (between $866 \pm 429 \mu \mathrm{S} \mathrm{cm}^{-1}$ in the colony soils and $748 \pm 517 \mu \mathrm{S}$ $\mathrm{cm}^{-1}$ in the control plot). The texture is dominated by fine fractions (silt and clay) (greater than68\%) relative to the sand fraction (Supplementary Table 1 ).

In both study zones, the yellow-legged gull populations are clearly in decline. In AINP, the population decreased from 16,837 pairs in 2011 to 10,795 pairs in 2015 (Barros, 2015). The same tendency has been observed in CNP, with 12,099 pairs in 2010 and 10,339 pairs in 2015 (Rizet, 2015). However, the worldwide population of the species is increasing (Birdlife International, 2017).

The characteristics of the plots selected in both parks are detailed in Table 1 . The cliffs under study were selected on the basis of the density of gulls, as follows: no gulls (control), low-intermediate density and high density, established in previous surveys of breeding gulls in each park.

\subsection{Sampling}

\subsubsection{Sampling of seabird excrement}

During the breeding period, samples of yellow-legged gull excrement were collected from the colonies, taking particular care not to include substrate material. The samples were placed in a cool box and transported to the laboratory, where they were frozen at $-80{ }^{\circ} \mathrm{C}$ until analysis. Each sample comprised 5-10 fresh excrements, which were 

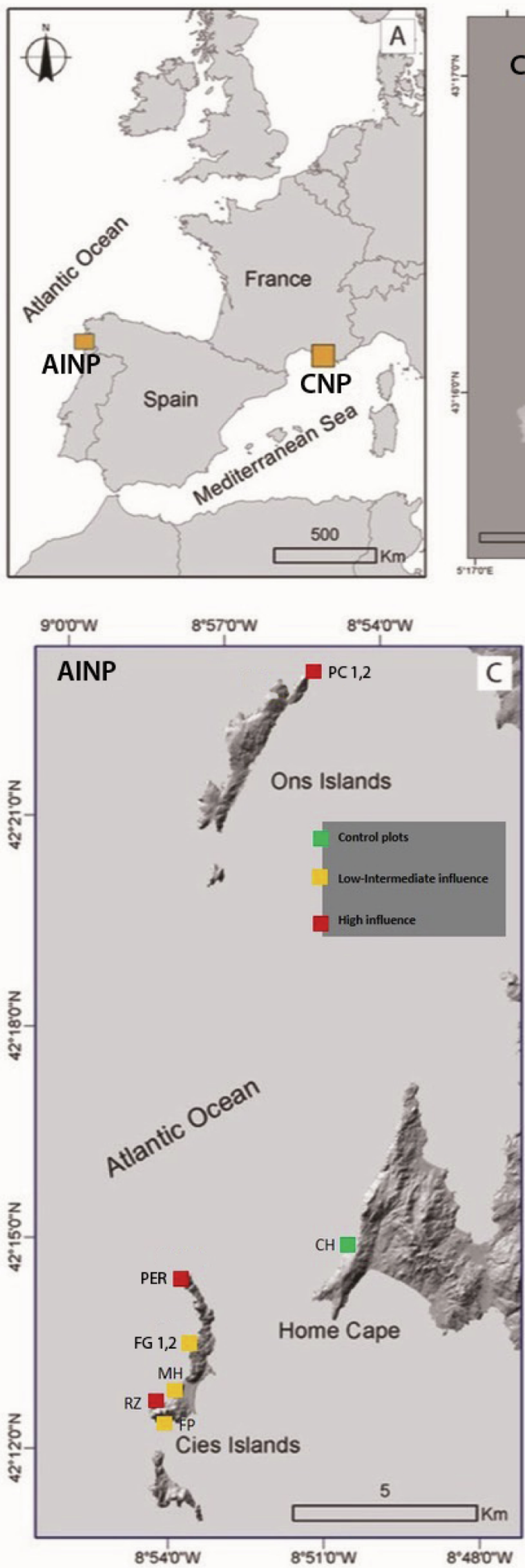
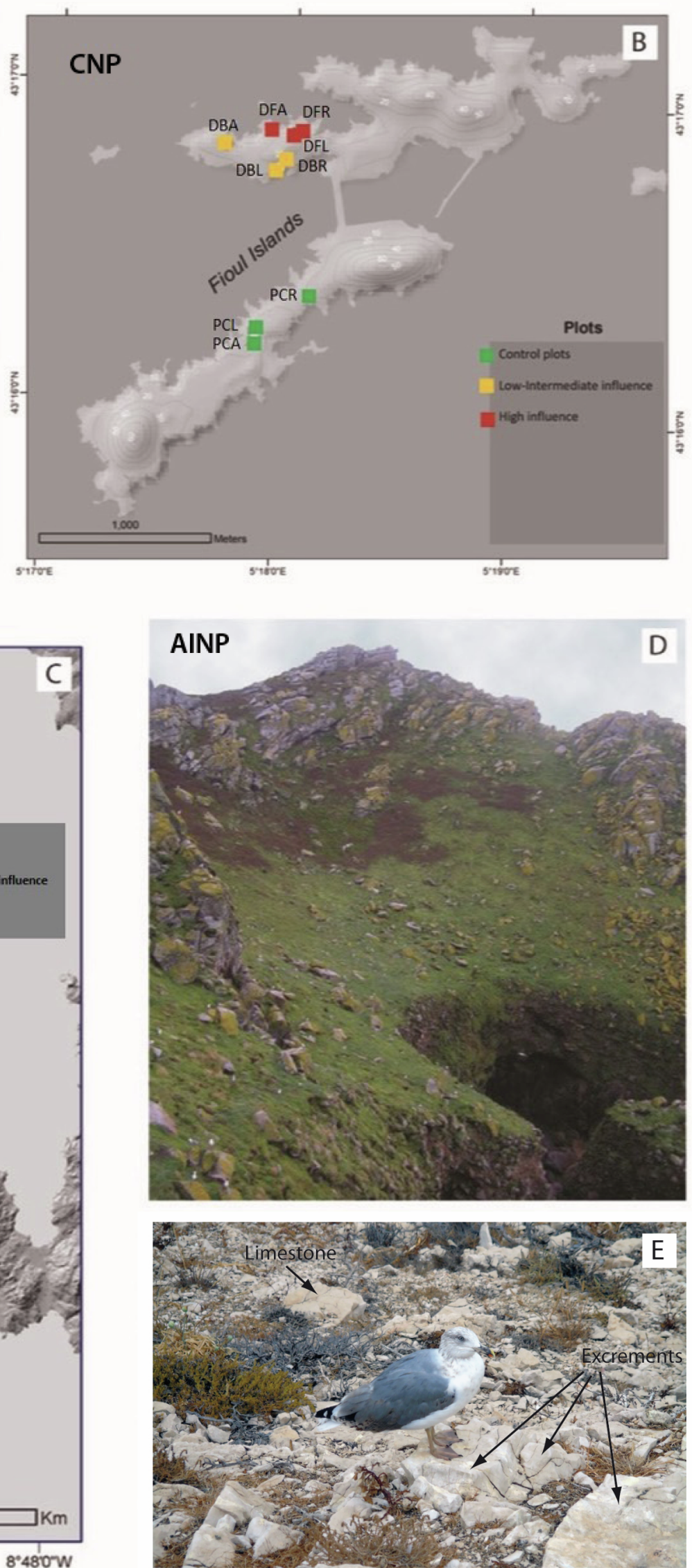

(caption on next page) 


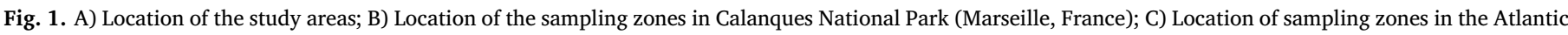

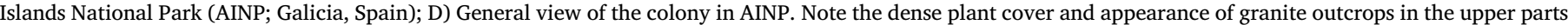
of the slopes. E) General view of the CNP colony. Note the rocky substrate (limestone) and scarce plant cover.

homogenized carefully. The concentrations of total $\mathrm{N}(\mathrm{TN})$, inorganic $\mathrm{N}$ $\left(\mathrm{N}-\mathrm{NO}_{3}{ }^{-}, \mathrm{N}-\mathrm{NH}_{4}{ }^{+}\right)$, total P (TP) and bioavailable P (P-bio) were determined.

\subsubsection{Soil sampling}

Soil sampling was carried out seasonally, in summer (AugustSeptember), which corresponds to the end of the breeding period when the density of the gulls in the colony is maximal, and in winter (February-March), when there are no gulls present in the colony.

- In AINP, the sampling was carried out in August and September in 2011 and 2012 and in February and March in 2011 and 2013, in gull colonies on Cíes and Ons islands and in the control zone (without gulls, Cabo Home) (Fig. 1B).

- In CNP, the sampling was carried out in September 2017 and in January 2018 (3 days after strong rainfall) in different parts of the Frioul archipelago with different densities of gulls, and in the control zone (without gulls) (Fig. 1C).

Two plots of $7 \times 5 \mathrm{~m}$ were established in the cliff sites - one in the lower and one in the upper part of the cliffs. In two sites (Monte das Herbas and Ruzo cliffs, AINP) only one plot was able to be established, in the middle part of the cliff. The plots were established in homogeneous areas, in terms of slope, stoniness and plant cover (see Otero et al., 2015, De la Peña et al., 2019).

A 50x50cm sampling frame was thrown to fall at random 6-8 times in each plot, and a sample of soil was taken from within the frame each time. Soil samples (0-15 cm depth) were collected within the frame with a trowel (length $20 \mathrm{~cm}$ ) and stored in plastic bags at $3-5{ }^{\circ} \mathrm{C}$ until analysis.

\subsection{Sample analysis}

The nitrogen forms $\left(\mathrm{N}-\mathrm{NH}_{4}{ }^{+}, \mathrm{N}-\mathrm{NO}_{3}{ }^{-}\right)$were determined in samples of excrement and soils. The samples $(5 \mathrm{~g})$ were extracted with $50 \mathrm{ml}$ of a $2 \mathrm{M} \mathrm{KCl}$ solution. The samples were maintained with continuous shaking for $1 \mathrm{~h}$ and were then filtered. Ammonia was determined by a steam distillation method. For this purpose, $5 \mathrm{ml}$ of indicator solution (boric acid, water and ethanol) was added to $20 \mathrm{ml}$ of the extract, along with $\mathrm{MgO}$, which enables conversion of the $\mathrm{NH}_{4}{ }^{+}$to $\mathrm{NH}_{3}$ in alkaline medium. Once the $\mathrm{NH}_{4}{ }^{+}$was extracted, $0.2 \mathrm{~g}$ of ball-milled Devarda's alloy was added to the same solution, to enable the reduction of $\mathrm{NO}_{3}{ }^{-}$to $\mathrm{NH}_{4}{ }^{+}$, which then forms $\mathrm{NH}_{3}$ and is steam distilled. Finally, the concentration of $\mathrm{NH}_{4}{ }^{+}$is determined by titration with a $0.005 \mathrm{~N} \mathrm{H}_{2} \mathrm{SO}_{4}$ solution and a mixed indicator of bromocresol green and methyl red (for more details on the method, see Mulvaney, 1996).

In air-dried soil samples $(0.5 \mathrm{~g})$, the total $\mathrm{P}$ (TP) was extracted by acid digestion ( $9 \mathrm{ml}$ of $14.4 \mathrm{M} \mathrm{HNO}_{3}: 3 \mathrm{ml}$ of $12 \mathrm{M} \mathrm{HCl}$ for $25 \mathrm{~min}$ ) in a microwave oven (Ethos Easy). Bioavailable P (P-bio) was extracted by the Mehlich 3 method (Mehlich, 1984), and crystalline Fe oxyhydroxides (FeD) were extracted with a sodium dithionite-citrate solution (0.5 M) (Holmgren, 1967). In addition, a few samples (3-4 per zone) were subjected to sequential $\mathrm{P}$ extraction. Two grams of dried, ground $(<2 \mathrm{~mm})$ soil were subjected to sequential extraction to yield the following P fractions (for further details, see Otero et al., 2015):

- F1-P: (P-ads), i.e. weakly adsorbed and soluble phosphorus. The sample was extracted with $20 \mathrm{ml}$ of $1 \mathrm{M} \mathrm{MgCl}_{2}$ solution, with continuous stirring for $30 \mathrm{~m}$. Samples were centrifuged at 10,000 rpm and filtered through Albet filter paper, and the extract thus obtained was stored at $3{ }^{\circ} \mathrm{C}$ until analysis. The residue was washed twice with Milli-Q water $(18 \Omega)$ before the next extraction was started. The centrifugation, filtration and washing procedures were repeated at the end of each extraction step.

- F2-P (P-Fe/Mn), i.e. P adsorbed to Fe and Mn oxides and oxyhydroxides. Twenty $\mathrm{ml}$ of a sodium bicarbonate-dithionite solution $\left(\mathrm{Na}_{2} \mathrm{~S}_{2} \mathrm{O}_{4} 0.11 \mathrm{M}+0.11 \mathrm{M} \mathrm{NaHCO}_{3} ; \mathrm{pH} 7\right)$ was added to the residue from the prior extraction, and the mixture was stirred continuously for $1 \mathrm{~h}$.

- F3-P (P-clay/Al), i.e. P bound to $\mathrm{Al}$ hydroxides and clay. The samples were shaken for $18 \mathrm{~h}$ with $20 \mathrm{ml}$ of sodium hydroxide $(0.1 \mathrm{M}$ $\mathrm{NaOH})$.

- F3b-P (P-HA), i.e. P associated with soil humic substances. The extract obtained in step F3 was dark brown (almost black) due to the dissolution of humic acids under alkaline conditions (Jiménez-Cárceles and Alvarez-Rogel, 2008). To avoid interference in the colorimetric quantification and for simultaneous quantification of the concentration of $\mathrm{P}$ associated with these soil components, the extract was acidified with $2.5 \mathrm{ml}$ of concentrated sulphuric acid $\left(\mathrm{H}_{2} \mathrm{SO}_{4}\right)$ and allowed to stand overnight. The organic flocs were allowed to settle at the bottom of the container before being separated by filtration. The filter with the retained material was dried $\left(45^{\circ} \mathrm{C}\right)$ and subsequently calcined at $520{ }^{\circ} \mathrm{C}$ for $2 \mathrm{~h}$ in a muffle furnace. The ash was dissolved in $5 \mathrm{ml}$ of $1 \mathrm{M} \mathrm{HCl}$ by boiling the mixture for $30 \mathrm{~min}$, and the extract was made up to $50 \mathrm{ml}$ with Milli-Q water.

- F4-P (P-Ca), i.e. $\mathrm{P}$ bound to Ca phosphates. The samples were shaken for $1 \mathrm{~h}$ with $20 \mathrm{ml}$ of $0.5 \mathrm{MHCl}$.

- F5-P (P-res), i.e. P mainly associated with refractory organic matter (Schlichting et al., 2002; Largeau, 2004). The material remaining after the above extractions was calcined and processed as described in step F3b-P (P-HA).

Reference material (NIST2782 and SO2) was used to determine the accuracy of the $\mathrm{P}$ extraction processes. The mean percent recovery of total $\mathrm{P}$ was $91 \pm 2 \%(\mathrm{n}=6$, and the sum of all fractions yielded by sequential extraction was $88.6 \pm 4 \%(n=3)$ (Otero et al. 2015).

The concentrations of total P (TP) and bioavailable P (P-bio) were determined colorimetrically, by the molybdenum blue method (Bowman, 1988). The P fractions and FeD were determined in an ICPOES spectrometer (Perkin Elmer Optima 4300 DV). All equipment used during extraction of the different $\mathrm{P}$ forms was washed thoroughly with $\mathrm{HCl}(5 \%)$, for at least $48 \mathrm{~h}$, and then with ultrapure water (Milli Q).

\subsection{Statistical analysis}

One-way ANOVA and a post hoc Holm-Sidack method test were used to detect significant differences between the mean concentrations of nutrients in excrement samples from each park, as well as differences in the mean nutrient concentrations between seasons (winter, summer), between sampling zones (control zone, low-intermediate density, high density) and overall between both national parks (CNP, AINP). Prior to ANOVA, all variables were checked for normality and homoscedasticity. Non-normally distributed data were transformed using a natural logarithm transformation. All statistical analyses were carried out using Sigma Plot 12,0. In all tests, a significance level of $\mathrm{p}<0.05$ was applied.

\section{Results}

\subsection{Nutrients in excrement}

The gull excrements contained high quantities of $\mathrm{N}$ and $\mathrm{P}$, and a high level of inter-sample variability was observed for both parks. The samples from AINP contained significantly higher amounts of TP and P- 


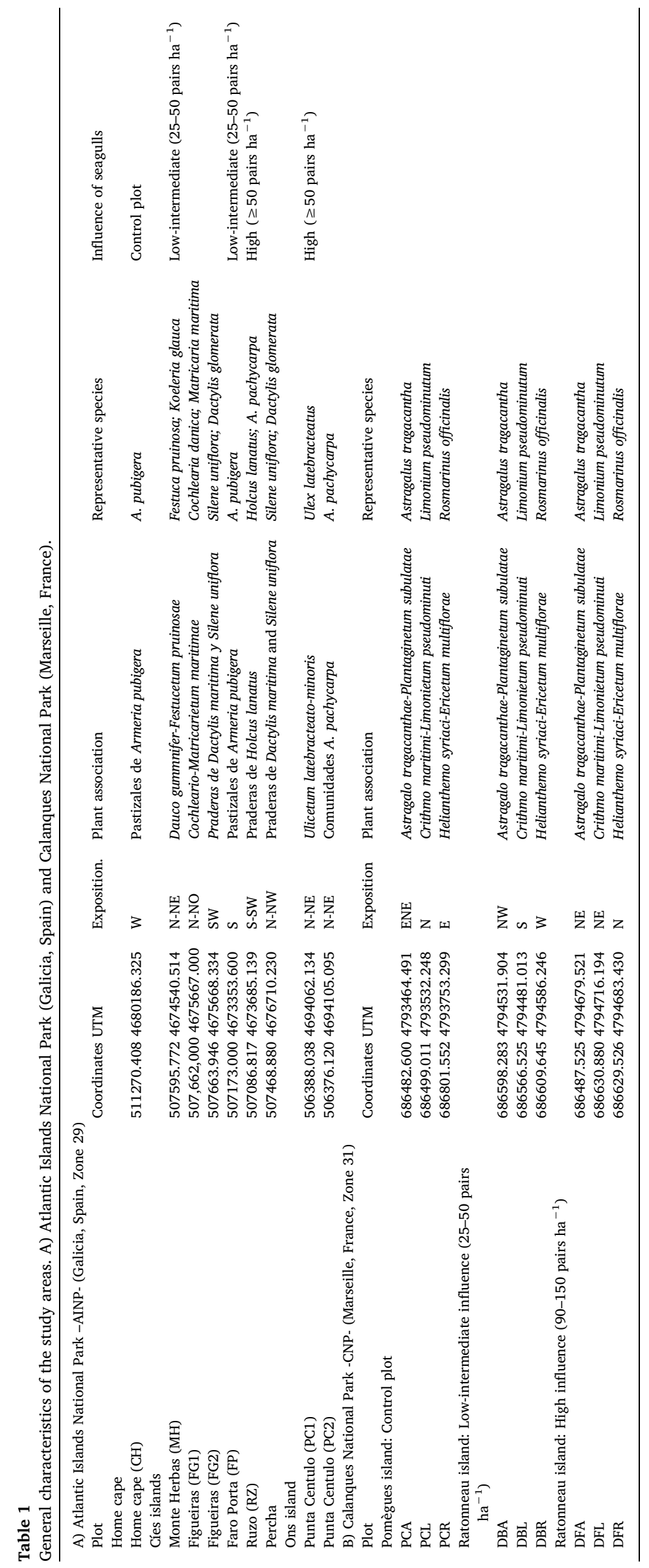


Table 2

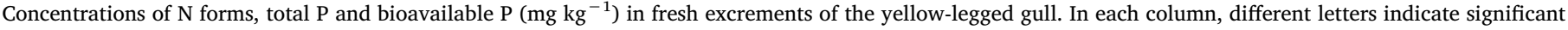
differences $(\mathrm{P}<0.05)$ between national parks.

\begin{tabular}{|c|c|c|c|c|}
\hline & \multicolumn{4}{|c|}{ Atlantic Islands National Park (AINP) } \\
\hline & $\mathrm{N}-\mathrm{NH}_{4}{ }^{+}$ & $\mathrm{N}-\mathrm{NO}_{3}{ }^{-}$ & Total P & P-bio \\
\hline Mean \pm SDMediann $=40$ & $\begin{array}{l}3,183 \pm 1,196 \mathrm{a}(2,991) \\
\text { Calanques National Park (CNP) }\end{array}$ & $73.3 \pm 203 a(5.56)$ & $27,617 \pm 21,424 \mathrm{a}(20,480)$ & $10,220 \pm 8,433 a(8,740)$ \\
\hline Mean \pm SDMediann $=5$ & $2,258 \pm 1,552 \mathrm{a}(2,362)$ & $12.8 \pm 9.8 \mathrm{a}(9.58)$ & $3,304 \pm 2,509 \mathrm{~b}(2,549)$ & $2,884 \pm 781 \mathrm{~b}(3,048)$ \\
\hline
\end{tabular}

bio (TP: 27,617 \pm 21,424 and P-bio: $10,220 \pm 8,433 \mathrm{mg} \mathrm{kg}^{-1}$, Table 2) than those from CNP. There was no significant difference in the concentrations of $\mathrm{N}$ forms between the parks (AINP: $\mathrm{N}^{-\mathrm{NH}_{4}}{ }^{+}=$ $3,183 \pm 1,196 \mathrm{mg} \mathrm{kg}^{-1}, \mathrm{~N}^{-N}{ }_{3}^{-}=73.3 \pm 203 \mathrm{mg} \mathrm{kg}^{-1}$; CNP: N$\mathrm{NH}_{4}{ }^{+}=2,258 \pm 1,552 \mathrm{mg} \mathrm{kg}{ }^{-1}, \mathrm{~N}^{-N}{ }_{3}{ }^{-}=12.8 \pm 9.8 \mathrm{mg} \mathrm{kg}{ }^{-1}$; Table 2).

\section{2. $N$ And $P$ in the gull colony soils}

In both parks, the colony soils contained significantly higher amounts of $\mathrm{N}$ forms and of $\mathrm{P}$ (especially bioavailable $\mathrm{P}$ ) than in the corresponding control zones (Table 3 ). In addition, the concentrations of $\mathrm{N}$ forms and P-bio were higher in AINP than in CNP (Table 3).

\subsubsection{Spatio-temporal variation in the $\mathrm{N}$ forms}

The concentrations of $\mathrm{N}^{-\mathrm{NH}_{4}}{ }^{+}$showed a marked seasonal variability in AINP but not in PNC. Thus, in CNP the mean concentrations of $\mathrm{N}-\mathrm{NH}_{4}{ }^{+}$in the colony soils were similar in summer (CNP: 14.2-25.3 $\mathrm{mg} \mathrm{kg}^{-1}$ ) and in winter (CNP: $10.8-16.9 \mathrm{mg} \mathrm{kg}^{-1}$; Fig. 2). In $\mathrm{CNP}$, there were no significant differences in the mean concentrations of $\mathrm{N}^{-\mathrm{NH}_{4}}{ }^{+}$in winter (CNP winter: $\mathrm{N}^{-\mathrm{NH}_{4}}$ high density $=16.9 \pm$ $11 \mathrm{mg} \mathrm{kg}^{-1}$; low-intermediate density: $10.8 \pm 4.2 \mathrm{mg} \mathrm{kg}^{-1}$; control zone: $8.96 \pm 3.5 \mathrm{mg} \mathrm{kg}^{-1}$; Fig. 2). However, in summer although there were no significant differences between the soil in low-intermediate density zone and the control soil, there were differences between the control plot and the high density colony (CNP summer: N$\mathrm{NH}_{4}{ }^{+}$high density $=25.3 \pm 13 \mathrm{mg} \mathrm{kg}^{-1}$; low-intermediate density: $14.2 \pm 8.8 \mathrm{mg} \mathrm{kg}^{-1}$; control zone: $11.0 \pm 5.2 \mathrm{mg} \mathrm{kg}^{-1}$; Fig. 2). A similar situation was observed in AINP in winter (CNP winter: $\mathrm{N}^{-} \mathrm{NH}_{4}{ }^{+}$ high density $=36.7 \pm 26 \mathrm{mg} \mathrm{kg}{ }^{-1}$; low-intermediate density: $28.6 \pm 23 \mathrm{mg} \mathrm{kg}^{-1}$; control zone: $27.2 \pm 27 \mathrm{mg} \mathrm{kg}^{-1}$; Fig. 2). In summer, the mean concentration of $\mathrm{N}^{-\mathrm{NH}_{4}}{ }^{+}$in the zone with a high density of gulls was statistically significantly higher than in the zone with a low-intermediate density of gulls, and the mean concentration in this zone was, in turn, significantly higher than in the control zone (Fig. 2). In summer, the mean concentration of $\mathrm{N}^{-\mathrm{NH}_{4}}{ }^{+}$in the colony soils was significantly higher than in the control zone (Fig. 2).

The seasonal pattern in the concentrations of $\mathrm{N}^{-\mathrm{NO}_{3}}{ }^{-}$was not the same as observed for $\mathrm{N}^{-\mathrm{NH}_{4}}{ }^{+}$in both parks. Thus, in CNP the highest concentrations occurred in winter, considering the three zones together, and in AINP, the highest concentrations occurred in summer, as observed for $\mathrm{N}^{-\mathrm{NH}_{4}}{ }^{+}$(Fig. 2).

\subsubsection{Spatio-temporal variation in the total (TP) and bioavailable $P(P$ -} bio) concentrations

The mean TP concentrations in the gull colony soils were similar in both parks (AINP: 1,211 \pm 957; CNP: 1,119 $\pm 620 \mathrm{mg} \mathrm{kg}^{-1}$, Table 3), while the concentration of P-bio was significantly higher in AINP than in CNP (AINP: $169 \pm 130$, CNP: $126 \pm 88 \mathrm{mg} \mathrm{kg}^{-1}$, Table 3). However, the increase in P-bio in the soils influenced by the gull colonies relative to the control plot did not differ significantly between the parks (AINP: $127 \pm 130 \mathrm{mg} \mathrm{kg}^{-1}$, CNP: $111 \pm 88 \mathrm{mg} \mathrm{kg}^{-1}$ ).

In CNP, significant seasonal differences in the TP concentrations were observed in both the control and colony soils, with the highest values occurring in summer (Fig. 3). In winter, there was a substantial decrease in the TP in all plots (e.g. high density of gulls: TP summer: $1,553 \pm 550$, TP winter $783 \pm 237 \mathrm{mg} \mathrm{kg}^{-1}$; Fig. 3). The TP content showed significant differences between control zones and colony soils but not between colonies.

In AINP, the TP concentrations were clearly affected by the presence of gulls, increasing with the density of gulls, as follows: control zone $<$ low-intermediate $<$ high density. By contrast, there were no significant seasonal differences in either the control zone or in the colony soils (Fig. 3). The soil in the control zone contained an unusually high amount of TP, presumably due to the presence of pegmatite intrusions with high contents of apatite (calcium phosphate) (IGME, 1981; González et al., 2013).

In both summer and winter in CNP, the concentration of P-bio in the zones with high densities of gulls was significantly higher (mean values winter/summer 131-153 mg kg ${ }^{-1}$ ) than in the zones with low densities of gulls (mean values winter/summer 133-87.5 mg kg${ }^{-1}$ ) and than in the control zone (winter: $15.4 \pm 8.8$, summer. $14.4 \pm 5.0 \mathrm{mg} \mathrm{kg}^{-1}$ ) (Fig. 3). Likewise, the concentrations were significantly higher in the zones with intermediate densities of gulls than in the control zone.

In AINP the concentration of P-bio was significantly higher in the colony soils than in the corresponding control soil (Fig. 3). The highest values corresponded to the plots with the highest density of gulls (summer: $185 \pm$ 52, winter: $199 \pm 44 \mathrm{mg} \mathrm{kg}^{-1}$ ), followed by zones with low-intermediate density of gulls (winter: $159 \pm 65$, summer

Table 3

Concentrations of $\mathrm{N}$ and $\mathrm{P}$ in colony soils and control soils in each national park, considering the summer and winter values together for the gull colony soils (lowintermediate and high density together) and for the control zone. In the rows, different capital letters indicate significant differences (at $p<0.05$ ) between corresponding zones in each park (e.g. control zone in the AINP and control zone in the CNP). Within each park, different lower-case letters indicate significant differences between different zones (control zone, colonies).

\begin{tabular}{|c|c|c|c|c|c|}
\hline & & \multicolumn{2}{|l|}{ CNP } & \multicolumn{2}{|l|}{ AINP } \\
\hline & & Control site & Colonies & Control site & Colonies \\
\hline & & \multicolumn{4}{|l|}{$\mathrm{mg} \mathrm{kg}^{-1}$} \\
\hline $\mathrm{N}-\mathrm{NH}_{4}{ }^{+}$ & mean \pm SDmediann & $9.99 \pm 4.5 \mathrm{Aa}(10.1) 36$ & $16.8 \pm 11 \mathrm{Ab}(13.7) 72$ & $31.5 \pm 21.1 \mathrm{Ba}(38.2) 22$ & $43.4 \pm 39.9 \mathrm{Bb}(34.8) 300$ \\
\hline $\mathrm{N}-\mathrm{NO}_{3}^{-}$ & mean \pm SDmediann & $8.29 \pm 7.7 \mathrm{Aa}(5.04) 36$ & $39.0 \pm 32 \mathrm{Ab}(26.9) 72$ & $25.6 \pm 17 \mathrm{Ba}(20.7) 22$ & $56.8 \pm 48 \mathrm{Bb}(45.7) 300$ \\
\hline Pbio & mean \pm SDmediann & $14.9 \pm 7.1 \mathrm{Aa}(14.5) 36$ & $126 \pm 88 \mathrm{Ab}(109) 72$ & $42.9 \pm 20 \mathrm{Ba}(35.9) 20$ & $169 \pm 130 \mathrm{Bb}(140) 260$ \\
\hline Total P & mean \pm SDmediann & $523 \pm 280 \mathrm{Aa}(431) 36$ & $1,119 \pm 620 \mathrm{Ab}(1,070) 72$ & $826 \pm 106 \mathrm{Ba}(808) 10$ & $1,211 \pm 957 \mathrm{Ab}(959) 100$ \\
\hline
\end{tabular}



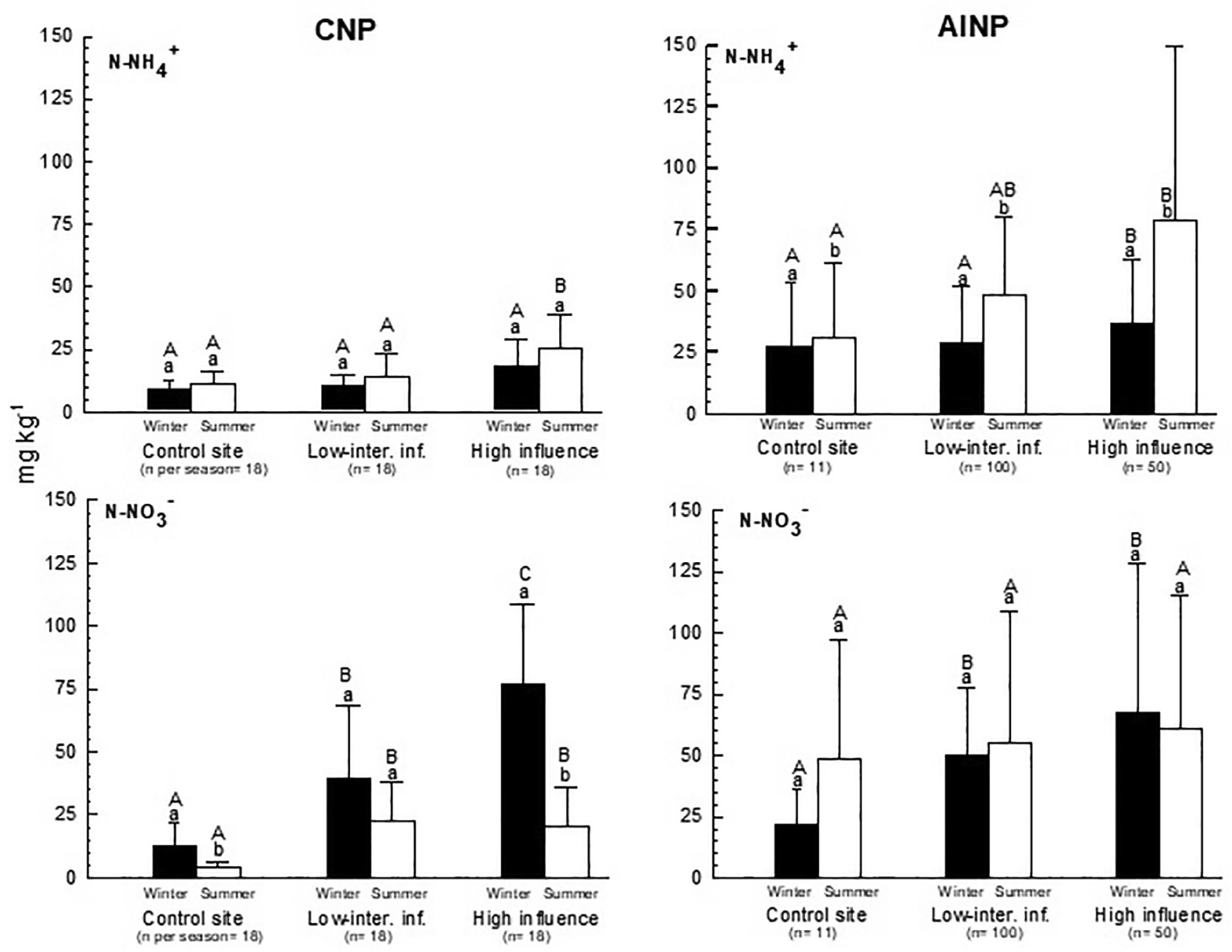

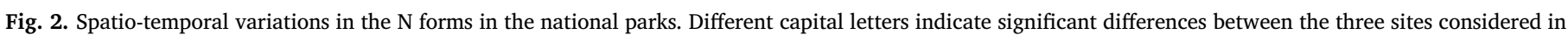

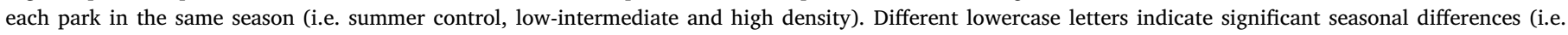
summer and winter) for each site.

$154 \pm 79 \mathrm{mg} \mathrm{kg}^{-1}$ ) and by the control zone (winter $54.5 \pm 24$, summer $32.5 \pm 8.10 \mathrm{mg} \mathrm{kg}{ }^{-1}$ ). The differences in P-bio between zones with high and low-intermediate densities of gulls did not show a clear pattern. Thus, in summer the concentrations were similar in both zones, while in winter the concentration of P-bio was significantly higher in the zone with a high density of gulls (Fig. 3).

\subsection{Phosphorus partitioning}

The distribution of $\mathrm{P}$ in the different geochemical fractions showed significant differences in the comparison between the colony and the corresponding control zone and the between-park comparison (Table 4).

In CNP, most of the P (96\%) was distributed between residual P (Pres: $872 \pm 185 \mathrm{mg} \mathrm{kg}^{-1}$ ) and $\mathrm{Ca}$ phosphate fractions (P-Ca: $708 \pm 397 \mathrm{mg} \mathrm{kg}^{-1}$, Table 4). These fractions were followed in abundance by the $\mathrm{P}$ associated with Fe oxides $(\mathrm{P}-\mathrm{Fe} / \mathrm{Mn}) \sim \mathrm{P}-\mathrm{HA}>\mathrm{P}$ clay/Al $\sim$ P-ads. By contrast, in AINP, the $\mathrm{P}$ was more homogeneously distributed. The dominant form was P-clay/Al (139 $\left.\pm 49 \mathrm{mg} \mathrm{kg}^{-1}\right)$, which represents $41 \%$ of the sum of the six fractions. The second most abundant P form was P-res, followed by P-Ca $>$ P-HA $\sim$ P-ads $>$ P$\mathrm{Fe} / \mathrm{Mn}$ (Table 4).

Finally, the concentrations of the most labile and mobile $P$ fractions (P-ads, P-HA) in soil were much higher in AINP than in CNP (AINP = Pads: $78.4 \pm 73$; P-HA: $87.7 \pm 34 \mathrm{mg} \mathrm{kg}^{-1}$; CNP $=$ P-ads:
$27.5 \pm 14 \mathrm{mg} \mathrm{kg}^{-1}$; P-HA: $35.2 \pm 12 \mathrm{mg} \mathrm{kg}^{-1}$ ).

\section{Discussion}

\subsection{Variability in nutrient concentrations in the excrements}

Seabird excrements are characterised by high concentrations of nutrients, particularly of $\mathrm{N}$ and $\mathrm{P}$ (García et al., 2002; Zwolicki et al., 2013; Otero et al., 2016, 2018). The high, variable concentrations of $\mathrm{N}$ and $\mathrm{P}$ in the excrements of the yellow-legged gull, as well as in other seabirds (see also Otero et al., 2015), appear to be derived from the diet. The yellow-legged gull is considered an opportunistic omnivore, incorporating substances of marine and terrestrial origin in its diet, along with a wide variety of waste products of anthropogenic and terrestrial origin (Pierotti and Annett, 1991; Munilla, 1997). A previous study in AINP has shown that various components of the gull diet occur in proportions higher than 5\%: waste remains (40.1\%), Polybius henslowii (36.4\%), Mytilus galloprovincialis (13.5\%), Micromesistius poutassou (9.8\%), Sardina pilchardus (8.4\%) and Trachurus spp. (7.6\%) (Munilla, 1997). Although the $\mathrm{N}$ and P contents of each of the elements that the gulls consume are not known, mussels (Mytilus galloprovincialis) cultivated in Galician rias have been found to contain much more $\mathrm{P}$ (314 mg/100 g) than populations from the Mediterranean Sea (149 mg/ 100 g Delta del Ebro; 239 mg/100 g Valencia) (Fuentes et al., 2009). This type of difference may partly explain the higher concentrations of 

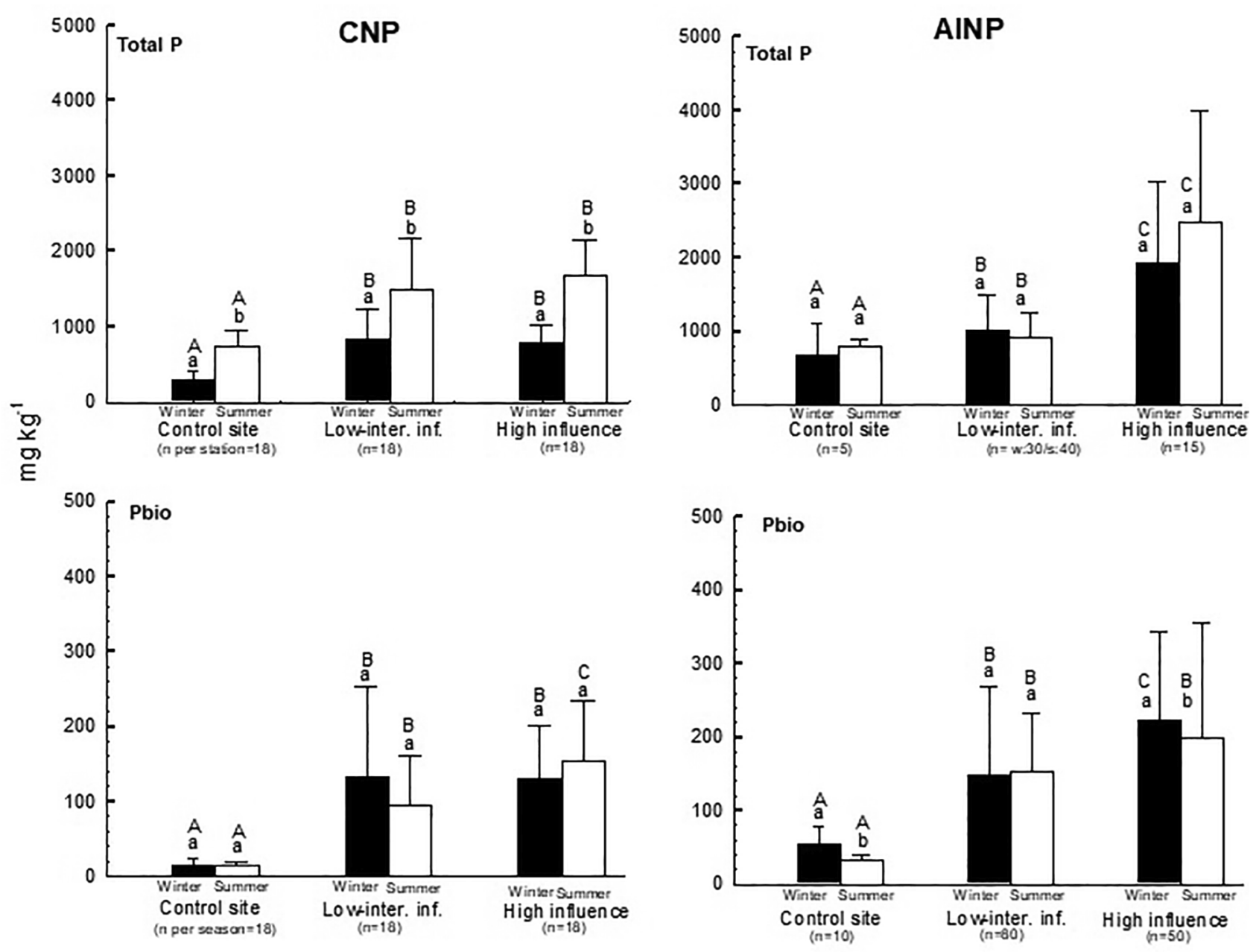

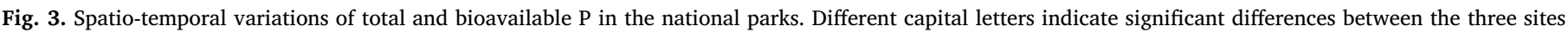

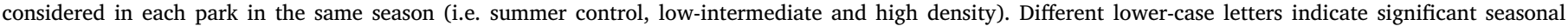
differences (i.e. summer and winter) for each site.

nutrients present in the excrements of the yellow-legged gull in AINP than in gulls from CNP ( 8 times more total $\mathrm{P}$ and 4 times more P-bio). Although there are no comparative data on populations of the same species, it has been concluded that differences in seabird diets represent the main cause of differences observed in tundra soils (Zwolicki et al., 2013; see also Hutchison, 1950; Bédard et al., 1980; Stempniewicz, 2005).

\subsection{Effect of environmental context on soil nutrient dynamics}

The results of the present study show that yellow-legged gull colonies exert a strong impact on $\mathrm{N}$ and $\mathrm{P}$ cycling in breeding colonies (Otero et al., 2000; 2015, García et al., 2002). However, other environmental factors in addition to nutrient supply can influence the mobility and bioavailability of these nutrients. Previous studies have highlighted the role of climate conditions on $\mathrm{N}$ dynamics (Riddick, 2012; Riddick et al., 2016), but as far as we are aware, no previous studies have considered the role of lithology on nutrient dynamics in seabird colony soils.

\subsubsection{N Dynamics}

The concentrations of $\mathrm{N}$ forms in soil were generally higher in AINP

Table 4

Geochemical forms of $\mathrm{P}$ in the soil $\left(\mathrm{mg} \mathrm{kg}^{-1}\right)$. Capital letters indicate significant differences between equivalent zones in each national park (e.g. control zone in the AINP and control zone in the CNP). Lowercase letters indicate significant differences in each P form between the control zone and the colony zone in the same national park (e.g. control zone and colony in the AINP).

\begin{tabular}{|c|c|c|c|c|}
\hline & \multicolumn{2}{|l|}{ CNP } & \multicolumn{2}{|l|}{ AINP } \\
\hline & control $(n=6)$ & colonies $(n=6)$ & control $(n=7)$ & colonies $(n=8)$ \\
\hline P-ads & $1.63 \pm 1.4 \mathrm{Ba}$ & $27.5 \pm 14 \mathrm{Ab}$ & $20.0 \pm 18 \mathrm{Aa}$ & $78.4 \pm 73 \mathrm{Ab}$ \\
\hline $\mathrm{P}-\mathrm{Fe} / \mathrm{Mn}$ & $6.26 \pm 1.7 \mathrm{Aa}$ & $37.1 \pm 13 \mathrm{Ab}$ & $24.1 \pm 9.74 \mathrm{Aa}$ & $46.3 \pm 27 \mathrm{Aa}$ \\
\hline P-clay/Al & $16.5 \pm 4.9 \mathrm{Ba}$ & $28.4 \pm 12 \mathrm{Ba}$ & $111 \pm 76 \mathrm{Aa}$ & $139 \pm 49 \mathrm{Aa}$ \\
\hline P-HA & $21.6 \pm 11 \mathrm{Aa}$ & $35.2 \pm 12 \mathrm{Ba}$ & $27.8 \pm 27 \mathrm{Aa}$ & $87.7 \pm 34 \mathrm{Ab}$ \\
\hline $\mathrm{P}-\mathrm{Ca}$ & $11.7 \pm 25 \mathrm{Ba}$ & $708 \pm 397 \mathrm{Ba}$ & $197 \pm 145 \mathrm{Aa}$ & $94.9 \pm 78 \mathrm{Aa}$ \\
\hline P-res & $527 \pm 193 \mathrm{Ba}$ & $872 \pm 186 \mathrm{Ba}$ & $31.8 \pm 20 \mathrm{Aa}$ & $104 \pm 79 A a$ \\
\hline
\end{tabular}


than in CNP, and in both parks they were highest at the end of summer (Tables 3,4 ), when the presence of gulls and chicks in the colony is greatest. However, a more detailed analysis shows that the seasonal patterns are more complex due to the high level of variability in both the between-park comparison and between-plot comparison in each

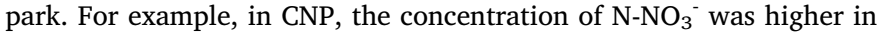
winter, whereas in AINP the corresponding values were highest in summer. The seasonal differences between parks suggest that environmental factors, especially climate factors (i.e. precipitation) modulate the impact of seabird colonies on nutrient dynamics (see e.g. Otero and Fernández-Sanjurjo, 2000; Otero et al., 2016; García et al. 2002).

The main $\mathrm{N}$ form present in seabird excrement is uric acid (Riddick, 2012). Uric acid undergoes diverse transformations in excrement that affect its geochemical mobility and loss from soil. Mineralization of organic $\mathrm{N}$ involves transformation into the ammonium ion $\mathrm{NH}_{4}{ }^{+}$, ammonification), which can be adsorbed onto soil colloids thereby reducing leaching from soil. However, transformation of $\mathrm{N}$ to nitrate $\left(\mathrm{NO}_{3}{ }^{-}\right.$, nitrification) favours $\mathrm{N}$ loss from soil during heavy rainfall (Bernal et al., 2002; Fenn and Poth, 1999). The elevated precipitation that usually occurs in AINP between October and March, together with the sandy soils, enhances this process in autumn and winter (Otero and Fernández-Sanjurjo, 2000). Despite the significant loss of $\mathrm{N}$ in the colony soils in AINP, the higher concentrations of inorganic $\mathrm{N}$ in the soil from AINP than in soil from CNP appear to indicate that the behaviour of $\mathrm{N}$ is less variable in the former than in the latter. In both parks the gull colonies are of similar size and developmental stage; however, the greater edaphic development, both at depth and at the surface (Fig. 1D), appears to contribute to greater retention of this element in the colony soils in AINP. The higher concentration of $\mathrm{N}$ in gull excrement in AINP may also contribute to the differences between the two parks.

In addition to $\mathrm{N}$ leaching, other geochemical processes that contribute to accelerating $\mathrm{N}$ loss may be particularly important in CNP. A high proportion of $\mathrm{N}$ (sometimes greater than 60\%) may be lost due to volatization as ammonia $\left(\mathrm{NH}_{3}\right)$ during the early stages of mineralization of the uric acid present in the excrement (Woodmansee, 1978). In $\mathrm{CNP}$, this process is favoured by high summer temperatures and the alkaline reaction between soils and limestone $\left(\mathrm{CaCO}_{3}\right)$ (Riddick et al., 2012). Moreover, $\mathrm{N}$ loss from excrement is greater when the excrement is deposited directly on the rock, as is usual in CNP (see Fig. 1E), than when it is deposited on soil or vegetation (see e.g. Lindeboom, 1984; Blackall et al., 2008). In fact, $\mathrm{NH}_{3}$ volatization from excrement is considered to be very low or nil when the excrement is deposited directly on vegetation (Riddick, 2012). These factors contribute to understanding why the concentrations of $\mathrm{N}^{-\mathrm{NH}_{4}}{ }^{+}$and $\mathrm{NO}_{3}{ }^{-}$were lower in the soils in CNP.

Furthermore, in Mediterranean climate zones, $\mathrm{N}$ cycling is strongly influenced by water availability in soil (Austin et al., 2004; OchoaHueso et al., 2011) and shows marked seasonal patterns (Bonilla and Rodà, 1992, Rutigliano et al., 2009). The concentration of inorganic N in soil is related to wetting-drying cycles that lead to lysis of microbial cells (Austin et al., 2004) and net mineralization of N (Bytnerowicz and Fenn, 1996; Fenn et al., 2009; Padgett et al., 1999). Regarding the results of the previously cited studies, the increase in $\mathrm{N}-\mathrm{NO}_{3}$ observed in winter in CNP may be may be due to the fact that sampling was conducted immediately after a period of rainfall following a prolonged drought period. The findings suggest that the winter rains may reactivate $\mathrm{N}$ mineralization processes (especially nitrification) after long dry periods that occur in arid climates.

Overall, the findings suggest that in CNP, mineralization of the organic $\mathrm{N}$ present in excrement occurs later in the year than in AINP, where the greater availability of water throughout almost of the year will favour nitrification processes in summer. In CNP this will not occur until after the first rainfall in autumn-winter.

\subsubsection{P dynamics}

The colony soils in both parks were enriched in $\mathrm{P}$, especially the most bioavailable forms (P-bio, P-ads), although also in the more recalcitrant forms (i.e. P-res, P-Ca). Thus, the concentration of P-bio in the colony soils was around 5-7 times higher than in the control zones. However, there were substantial differences between the zones in the annual dynamics. The behaviour of $\mathrm{P}$ in the soil also differed, which affected both the total $\mathrm{P}$ content and the geochemical forms of $\mathrm{P}$.

The TP content of the colony soils in AINP was almost identical in summer and winter, whereas in CNP the TP content was much higher in summer than in winter (Fig. 3). The lower TP in CNP is consistent with the intense precipitation that occurs in winter in Mediterranean climate zone, which causes high rates of run-off and strong erosion of the soil surface (Plan Blue, 2003) and also loss of the P accumulated on the soil surface during the breeding period.

In addition to the $\mathrm{P}$ enrichment observed in the yellow-legged gull colony soils, the $\mathrm{P}$ fractioning indicated differences in geochemical forms that were consistent with marked edapho-geochemical differences (depth, texture, $\mathrm{pH}$, organic matter content, etc. Table S1) between the national parks.

The order of abundance of the different $\mathrm{P}$ forms in the yellow-legged gull excrement was as follows: P-Ca $\gg$ P-res $>$ P-Fe/Mn $\sim$ P-HA $>$ Pads P-clay/Al (Otero et al., 2015). In both parks, P-Ca was one of the main P forms present in the soil (Table 4), which is consistent with the concentration in the excrements, although also with its presence in the parent material (granites and pegmatites with apatite) in AINP. However, in CNP the concentration of P-Ca reached extremely high values, around 7 times higher than in AINP (CNP: $708 \pm$ 397, AINP: $94.9 \pm 78 \mathrm{mg} \mathrm{kg}^{-1}$ ), while the other geochemical forms were present at very low concentrations (in general median values $<40 \mathrm{mg} \mathrm{kg}^{-1}$ ), except for the residual fraction, which was the most abundant. The $\mathrm{P}$ incorporated in calcareous soils undergoes a series of fixation reactions that lead to rapid (weeks) immobilization in the soil. Phosphorus fixation is a combination of surface adsorption on clay and lime, and precipitation of various calcium phosphate minerals (mainly dicalcium phosphate and octacalcium phosphate), which gradually decrease the solubility and availability of P to plants, especially in young calcareous soils with high concentrations of P (Carreira and Lajtha, 1997; Tunesi et al., 1999, Wandruszaka, 2006). This process explains the enrichment of the P-Ca fraction to the detriment of the other geochemical fractions in the soils in CNP.

In addition, the low importance of Fe oxides and hydroxides in the colony soils in CNP is consistent with the alkaline nature of the soil, which leads to reduction in the positive charge of these colloids (see below), and also with the low concentration of Fe oxyhydroxides in the soil (CNP colonies FeD: $0.07 \pm 0.03 \%$, Table S1). The same reasoning can be applied to the small part that the clays and $\mathrm{Al}$ oxyhydroxides play in controlling the mobility of P in colony soils in CNP.

By contrast, in acid soils the P solubility is mainly determined by $\mathrm{Fe}$ and $\mathrm{Al}$ oxyhydroxides (Wild, 1993). This is particularly relevant in AINP, as together these P-associated fractions represent almost $30 \%$ of the total $\mathrm{P}$, which is consistent with the higher content of $\mathrm{Fe}$ oxyhydroxides than in CNP (AINP colonies FeD: 0.11-0.14\%). In addition, the positive charge associated with the surfaces of the $\mathrm{Fe}$ and $\mathrm{Al}$ oxyhydroxides, as well as the edges of the phyllosilicates in the clay fraction confer the soil the capacity to adsorb oxyanions such as orthophosphate (Equation 1, 2).

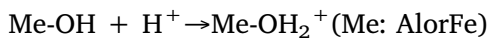

$\mathrm{Me}-\mathrm{OH}_{2}{ }^{+}+\mathrm{H}_{2} \mathrm{PO}_{4}{ }^{-} \rightarrow \mathrm{Me}-\mathrm{O}-\mathrm{PO}_{3} \mathrm{H}_{2}+\mathrm{H}_{2} \mathrm{O}$

However, this process and the posterior migration of $\mathrm{P}$ into the soil particles (mainly $\mathrm{Al}$ and $\mathrm{Fe}$ oxides and hydroxides) or conversion of dicalcium-P (DCP) into octacalcium-P or apatite usually leads to a huge reduction in the bioavailable $\mathrm{P}$ and particularly the weakly adsorbed $\mathrm{P}$ (P-ads), an important fraction in the gull colony soils in AINP 
(representing $11 \%$ of the TP). The high concentration of P-ads is compatible with the fact that the colony soils in AINP are saturated in $\mathrm{P}$ due to the input from the yellow-legged gull (for further details, see Otero et. al. 2015).

Unlike in CNP, the P fraction associated with humic acids was also an important fraction in AINP. The P-HA represented 13\% of the TP in AINP, which is consistent with the high content of organic $C$ in the colony soils and the high primary productivity observed in the yellowlegged gull colonies relative to the control zone (Fig. 1E). The dominant forms of organic P in the colony soils in AINP were orthophosphate monoesters (39.5\%; Otero et al., 2015), which are the major functional and most stable class of organic P in most soils (Turner et al., 2001). Furthermore, output of orthophosphates is known to occur via the small temporary streams that run through the colony, as well as loss of high amounts of dissolved organic carbon (DOC) in the run-off from the colonies (DOC colonies: $12.2 \pm 8.1 \mathrm{mg} \mathrm{l}^{-1}$; Otero et al., 2015) relative to the amount present in the rivers that run through forest areas in Cíes Islands $\left(6.0 \pm 4.5 \mathrm{mg} \mathrm{l}^{-1}\right)$. Orthophosphate and dissolved organic $\mathrm{P}$ (DOP) are $\mathrm{P}$ forms that are bioavailable to marine plankton (Dyhrman and Ruttenberg 2006) and therefore seabird colonies may represent an important source of input of $\mathrm{P}$ (and N) to coastal waters (Otero et al., 2015, 2018).

The lower concentration of P-bio in summer in the soils in CNP is also related to the strong seasonal variations that characterize the Mediterranean climate as the mineralization of organic phosphates is a slow process and subject to wetting-drying cycles (Lebedjantzev, 1924, Read and Mitchell, 1983), which lead to the release of important amounts of phosphorus.

\section{Conclusions}

In both national parks, yellow-legged gull colonies exert a strong impact on $\mathrm{N}$ and $\mathrm{P}$ cycling, in an effect recently denominated ornithoeutrophication (Otero et al. 2018). However, annual N and P cycles are strongly influenced by environmental conditions.

In CNP, mineralization of the organic $\mathrm{N}$ in the excrement occurs more slowly in the summer due to the very dry conditions at this time of year, but is reactivated by the first rainfall in autumn-winter. This leads to higher concentrations of $\mathrm{N}^{-\mathrm{NO}_{3}}{ }^{-}$in winter than in summer, in contrast to what occurs in AINP.

The annual $\mathrm{P}$ dynamics are more strongly conditioned by edaphic and lithological conditions than by climatic conditions. In CNP, calcium phosphate acts as a sink for the P released on mineralization of the gull excrement due to the high concentration of calcium carbonate in the soil. By contrast, in AINP, where the soils are characteristically acidic or strongly acidic, the $\mathrm{P}$ is distributed more homogeneously between the different geochemical fractions.

\section{Declaration of Competing Interest}

The authors declare that they have no known competing financial interests or personal relationships that could have appeared to influence the work reported in this paper

\section{Acknowledgements}

The authors are grateful to the managers and technicians at AINP for the support and facilities provided during the fieldwork. Thanks are also due to María José Santiso, for assistance with laboratory work, and to Esther Sierra Abraín, Pablo Montero and Adrián González, for help with sampling. This work is part of a research project entitled "Monitorización de los procesos biogeoquímicos en suelos de acantilados y aguas costeras en relación con la influencia de las colonias de aves marinas del Parque Nacional Marítimo Terrestre de las Islas Atlánticas de Galicia", funded by Organismo Autónomo Parques Nacionales (Ref. 041/2010, Ministerio de Medio Ambiente, Medio Rural y Marino), Fundación
BBVA and Cross-Research in Environmental Technologies (CRETUS) (AGRUP 2015/02, ref. 2018-P G100) and Consellería de Educación, Universidade e Formación P rofesional-Xunta de Galicia (Axudas á consolidación e estruturación de unidades de investigación competitivas do SUG del Plan Galego IDT, Ambiosol Group ref. 2018-PG036). Saúl de La Peña was in receipt of a predoctoral fellowship from the FPU P rogram of Spanish Ministry of Education and Innovation. We also thank Christine Francis for improving the English translation.

\section{References}

Allué, A.J.L. 1966. Subrregiones fitoclimáticas de España. I.F.I.E. Ed Minist. Agricultura. Madrid.

Austin, A.T., Yahdjian, L., Stark, J.M., Belnap, J., Porporato, A., Norton, U., Ravetta, D.A., Schaeffer, S.M., 2004. Water pulses and biogeochemical cycles in arid and semiarid ecosystems. Oecologia 141, 221-235. https://doi.org/10.1007/s00442-004-1519-1. Barros, A., 2015. Censo da poboación reprodutora de corvo mariño cristado

(Phalacrocorax aristotelis), gaivota patiamarela (Larus michahellis), gaivota escura (Larus fuscus) e gaivotón (Larus marinus) no Parque Nacional Marítimo-Terrestre das Illas Atlánticas de Galicia: resultados de 2015. Parque Nacional Marítimo-Terrestre das Illas Atlánticas de Galicia. Informe non publicado, Xuño de, pp. 2015.

Bédard, J., Therriault, J.C., Berube, J., 1980. Assessment of the importance of nutrient recycling by seabirds in the St. Lawrence Estuary. Can. J. Fish. Aquat. Sci. 37, 583-588. https://doi.org/10.1139/f80-074.

Bernal, S., Butturini, A., Sabater, F., 2002. Variability of DOC and nitrate responses to storms in a small Mediterranean forested catchment. Hydrol. Earth Syst. Sci. 6, 1031-1041.

BirdLife International, 2017. Species factsheet: Larus michahellis. Downloaded from http://www.birdlife.org on. 22/11/2017.

Blackall, T.D., Wilson, L.J., Bull, J., Theobald, M.R., Bacon, P.J., Hamer, K.C., Wanless, S., Sutton, M.A., 2008. Temporal variation in atmospheric ammonia concentrations above seabird colonies. Atmos. Environ. 42, 6942-6950. https://doi.org/10.1016/j. atmosenv.2008.04.059.

Bonilla, D., Rodà, F., 1992. Soil nitrogen dynamics in a Holm oak forest. Vegetation 99-100, 247-357. https://doi.org/10.1007/BF00118231.

Bonnet, V., Vidal, E., Médail, F., Tatoni, T., 1999. Analyse diachronique des changements floristiques sur un archipel méditerranéen périurbain (îles du Frioul, Marseille). Revue d'écologie 54, 16.

Bowman, R.A., 1988. A rapid method to determine total phosphorus in soils. Soil Sci. Soc. Am. J. 52, 1301-1304.

Bytnerowicz, A., Fenn, M.E., 1996. Nitrogen deposition in California forests: a review. Environ. Pollut. 92, 127-146. https://doi.org/10.1016/0269-7491(95)00106-9.

Carreira, J.A., Lajtha, K.L., 1997. Factors affecting phosphate sorption along a Mediterranean dolomite soil and vegetation chronosequence. Eur. J. Soil Sci. 1997 (48), 139-149. https://doi.org/10.1111/j.1365-2389.1997.tb00193.x.

De La Peña-Lastra, S., Pérez-Alberti, A., Otero, X.L., 2018. Enrichment of trace elements in colonies of the yellow-legged gull (Larus michahellis) in the Atlantic Islands National Park (Galicia-NW Spain). Sci. Total Environ. 648, 1536-1548. https://doi.org/10. 1016/j.scitotenv.2018.08.284

Douguedroit, A., 1983. La sécheresse à Marseille: un siècle de longues séquences sèches (études statistiques). Météorologie 34, 188-190.

Dyhrman, S.T., Ruttenberg, C.K., 2006. Presence and regulation of alkaline phosphatase activity in eukaryotic phytoplankton from the coastal ocean: implications for dissolved organic phosphorus remineralization. Limnol. Oceanogr. 51, 1381-1390. https://doi.org/10.4319/lo.2006.51.3.1381.

Fenn, M.E., Poth, M.A., 1999. Temporal and spatial trends in streamwater nitrate concentrations in the San Bernardino Mountains, southern California. J. Environ. Qual. 28, 822-836. https://doi.org/10.2134/jeq1999.00472425002800030013x.

Fenn, M. E., Sickman, J. O., Bytnerowicz, A., Clow, D. W., Molotch, N. P., Pleim, J. E., Tonnesen, G. S., Weathers, K. C., Padgett, P. E., Campbell, D. H. 2009. Methods for measuring atmospheric nitrogen deposition inputs in arid and montane ecosystems of western North America. In: Legge, A. H. (Ed.), Air Quality and Ecological Impacts: Relating Sources to Effects. Developments in Environmental Science, vol. 9. Elsevier, Amsterdam, pp. 179-228.

Fuentes, A., Fernández-Segovia, I., Escriche, I., Serra, J.A., 2009. Comparison of physicochemical parameters and composition of mussels (Mytilus galloprovincialis Lmk.) from different Spanish origins. Food Chem. 112 (2), 295-302. https://doi.org/10.1016/j. foodchem.2008.05.064.

Galarza, A., 2015. Is the population of Cantabrian yellow-legged gull Larus michahellis lusitanius Naumann, 1840 decreasing? 2013/2014 Census in Biscay (Basque Country). Munibe, Cienc nat 63, 135-143. https://doi.org/10.21630/mcn.2015.63.07.

García, L.V., Marañón, T., Ojeda, F., Clemente, L., Redondo, R., 2002. Seagull influence on soil properties, chenopod shrub distribution, and leaf nutrient status in semi-arid Mediterranean islands. Oikos 98, 75-86. https://doi.org/10.1034/j.1600-0706.2002. 980108.x.

IGME (Instituto Geologico y Minero de España),, 1981. Mapa geológico de España, Serie 
MAGMA hoja 223 (Vigo). IGME, Madrid.

González, L., et al., 2013. Guia Geológica del Parque Nacional de las Islas Atlánticas de Galicia. IGME, Madrid. España, pp. 1-202.

Guitián, J., Guitián, P., 1989. La influencia de las colonias de aves marinas en la vegetación de los acantilados del noroeste ibérico. Bol Soc Brot Ser 62, 77-86.

Hogg, E.H., Morton, J.K., 1983. The effect of nesting gulls on the vegetation and soil of islands in the great lakes. Can. J. Bot. 61, 3240-3254.

Holmgren, G.G., 1967. A rapid citrate-dithionite extractable iron procedure. Soil Sci. Soc. Am. Proc. 31, 210-2011.

Hutchison, G.E., 1950. Survey of contemporary knowledge of biochemistry. 3. The biochemistry of vertebrate excretion. Bull Am Mus Nat Hist 96, 1-554.

Jiménez-Cárceles, F.J., Alvarez-Rogel, J., 2008. Phosphorus fractionation and distribution in salt marsh soils affected by mine wastes and eutrophicated water: a case study in SE Spain. Geoderma 144, 299-309.

Largeau, C., 2004. Refractory macromolecular fraction of soil organic matter: chemical composition, sources and relationship with the stable fraction. Eurosoil Meeting, Freiburg.

Lebedjantzev, A.N., 1924. Drying of soil, as one of the natural factors in maintaining soil fertility. Soil Sci. 18, 419-447.

Lindeboom, H.J., 1984. The nitrogen pathway in a penguin rookery. Ecology 65 , 269-277. https://doi.org/10.2307/1939479.

Médail, F., Quézel, P., 1999. Biodiversity hotspots in the Mediterranean basin: setting global conservation priorities. Conserv. Biol. 13, 1510-1513. https://doi.org/10. 1046/j.1523-1739.1999.98467.x.

Mehlich, A., 1984. Mehlich 3 soil test extractant: a modification of the Mehlich 2 extractant. Commun. Soil Sci. Plant Anal. 15, 1409-1416. https://doi.org/10.1080/ 00103628409367568.

Meteogalicia 2018. Consellería de Medio Ambiente, Territorio e Infraestruturas - Xunta de Galicia Santiago de Compostela. A Coruña. Disponible en: http://www2.meteogalicia.es/galego/observacion/estacions/ Consulta: Noviembre de 2018.

Mouriño, J., Otero, X.L., 2002. Caracterización de la vegetación de los acantilados del Parque Natural de las Islas Cíes y su relación con la colonia de gaviota patiamarilla (Larus cachinnans). Cuad Soc Esp Cien Fpr 14, 135-142.

Mulvaney, R. L. 1996. Nitrogen-Inorganic forms. In: D. L. Sparks (Eds.) Methods of soil analysis. Part 3. Chemical Methods. Soil Science Society of America, Inc, American Society of Agronomy, Inc. Madinson. USA, pp. 1123-1184.

Munilla, I., 1997. Henslow's swimming crab (Polybius henslowii) as an important food for yellow-legged gulls (Larus cachinnans) in NW Spain. ICES J. Mar. Sci. 54, 631-634. https://doi.org/10.1006/jmsc.1997.0249.

Ochoa-Hueso, R., Allen, E.B., Branquinho, C., Cruz, C., Dias, T., Fenn, M.E., Manrique, E., Pérez-Corona, E., Sheppard, L.J., Stock, W.D., 2011. Nitrogen deposition effects on Mediterranean-type ecosystems: An ecological assessment. Environ. Pollut. 159 (10), 2265-2279. https://doi.org/10.1016/j.envpol.2010.12.019.

Oro, D., Bosch, M., Ruíz, X., 1995. Effects of a trawling moratorium on the breeding success of the Yellow-legged gull Larus cachinnans. Ibis 137 (4), 547-549. https://doi. org/10.1111/j.1474-919X.1995.tb03265.x.

Otero, X. L., De la Peña-Lastra, S., Pérez-Alberti, A., Macías, F. 2016. Variabilidad espaciotemporal de formas de nitrógeno y fósforo en suelos de las colonias de gaviota patiamarilla (Larus michaellis, Naumann 1840) en el Parque Nacional MarítimoTerrestre de las Islas Atlánticas de Galicia. In: Organismo Autónomo de Parques Nacionales (Ed.), Proyectos de investigación en parques nacionales: 2011-2014. pp 123-140.

Otero, X.L., Fernández Sanjurjo, M.J., 2000. Seasonal variation in inorganic nitrogen content of soils from breeding sites of yellow-legged gulls (Larus Cachinnans) in the Cies Islands Natural Park (NW Iberian Peninsula). Fresenius Envion. 8, 685-692.

Otero, X.L., Tejada, O., Martín-Pastor, M., De la Peña, S., Ferreira, T.O., Pérez-Alberti, A., 2015. Phosphorus in seagull colonies and the effect on the habitats. The case of yellow-legged gulls (Larus michahellis) in the Atlantic Islands National Park (GaliciaNW Spain). Sci. Total Environ. 532, 383-397. https://doi.org/10.1016/j.scitotenv. 2015.06.013.

Otero, X.L., De La Peña-Lastra, S., Romero, D., Nóbrega, G.N., Ferreira, T.O., PérezAlberti, A., 2018. Trace elements in biomaterials and soils from a yellow-legged gull (Larus michahellis) colony in the Atlantic Islands of Galicia National Park (Galicia-NW Spain). Mar. Pollut. Bull. 133, 144-149. https://doi.org/10.1016/j.marpolbul.2018. 05.027.

Otero, X. L., Pérez-Alberti, A. 2009. Parque Nacional de Marítimo Terrestre de las Islas Atlánticas de Galicia. Ed. Lunwerg.

Padgett, P.E., Allen, E.B., Bytnerowicz, A., Minnich, R.A., 1999. Changes in soil inorganic nitrogen as related to atmospheric nitrogenous pollutants in southern California. Atmos. Environ. 33, 769-781. https://doi.org/10.1016/S1352-2310(98)00214-3.

Pierotti, R., Annett, C.A., 1991. Diet choice in the Herring Gull: constraints imposed by reproductive and ecological factors. Ecology 72 (1), 319-328. https://doi.org/10. $2307 / 1938925$.

Plan Blue (2003). Threats to Soils in Mediterranean Countries. UNEP. http://www.prosodol.gr/sites/prosodol.gr/files/Threats\%20of\%20soils\%20Med.pdf.

Ramos, R., Ramírez, F., Sanpera, C., Jover, Ll, Ruiz, X., 2009. Diet of Yellow-legged Gull (Larus michahellis) chicks along the Spanish Western Mediterranean coast: the relevance of refuse dumps. J. Ornithol. 150, 265-272. https://doi.org/10.1007/ s10336-008-0346-2.

Read, D.J., Mitchell, D.T., 1983. Decomposition and mineralization processes in Mediterranean-type ecosystems and in heathlands of similar structure. In: Kruger, F.J., Mitchell, D.T., Jarvis, J.U.M. (Eds.), Mediterranean-type ecosystems: the role of nutrients. Springer, Berlin Heidelberg New York, pp. 208-232.

Riddick, S. N. 2012. The Global Ammonia Emission from Seabirds. (PhD Dissertation, King's College, London).

Riddick, S.N., Dragosits, U., Blackall, T.D., Daunt, F., Wanless, S., Sutton, M.A., 2012. The global distribution of ammonia emissions from seabird colonies. Atmos. Environ. 55, 319-327. https://doi.org/10.1016/j.atmosenv.2012.02.052.

Riddick, S.N., Dragosits, U., Blackall, T.D., Daunt, F., Braban, C.F., Tang, Y.S., Newell, M., Schmale, J., Hill, P.W., Wanless, S., Sutton, M.A., 2016. Measurement of ammonia emissions from temperate and polar seabird colonies. Atmos. Environ. 134, 40-50.

Rizet, F., 2015. Dynamique de la population de goélands leucophée (Larus michahellis N., 1840) sur les îles de Marseille et test de la méthode de Distance Sampling. Mémoire de M2 Ecole Pratique des Hautes Etudes. Année universitaire, 2014-2015.

Rutigliano, F.A., Castaldi, S., D’Ascoli, R., Papa, S., Carfora, A., Marzaioli, R., Fioretto, A., 2009. Soil activities related to nitrogen cycle under three plant cover types in Mediterranean environment. Appl. Soil Ecol. 43, 40-46. https://doi.org/10.1007/ BF00239162.

Signa, G., Mazzola, A., Tramiti, C.D., Vizzini, S., 2013. Gull-derived trace elements trigger small-scale contamination in a remote Mediterranean nature reserve. Mar. Pollut. Bull. 74, 237-243. https://doi.org/10.1016/j.marpolbul.2013.06.051.

Schlichting, A., Leinweber, P., Meissner, R., Altermann, M., 2002. Sequentially extracted phosphorus fractions in peat-derived soils. J. Plant Nutr. Soil Sci. 165, 290-298.

Sobey, G.G., Kenworthy, J.B., 1979. The relationship between herring gulls and the vegetation of their breeding colonies. J. Ecol. 67, 469-496.

Sposito, G., 1989. The Chemistry of Soils. Oxford University Press, New York.

Stempniewicz, L., 2005. Keystone species and ecosystem functioning. Seabirds in polar ecosystems. Ecol Quest 6, 111-115.

Tunesi, S., Poggi, V., Gessa, C., 1999. Nutr. Cycl. Agroecosyst. 53, 219. https://doi.org/ 10.1023/A:1009709005147.

Turner, B.L., Bristow, A.W., Haygarth, P.M., 2001. Rapid estimation of microbial biomass in grassland soils by ultra-violet absorbance. Soil Biol. Biochem. 33, 913-919.

Vidal, E., Médail, F., Tatoni, T., Bonnet, V., 2000. Seabirds drive plant species turnover on small Mediterranean islands at the expense of native taxa. Oecologia 122, 427-434. https://doi.org/10.1007/s004420050049.

Vidal, E., Médail, F., Tatoni, T., 1998a. Is the yellow-legged gull a superabundant bird species in the Mediterranean? Impact on fauna and flora, conservation measures and research priorities. Biodiv Conserv 7, 1013-1026. https://doi.org/10.1023/ A:1008805030578.

Vidal, E., Médail, F., Tatoni, T., Vidal, P., Roche, P., 1998b. Functional analysis of the newly established plants, induced by nesting gulls on Riou archipelago (Marseille France). Acta Oecol 19, 241-1240. https://doi.org/10.1016/S1146-609X(98) 80028-3.

Vidal, E., Médail, F., Tatoni, T., Roche, P., Vidal, P., 1998c. Impact of gull colonies on the flora of the Riou archipelago (Mediterranean islands of SE France). Biol. Conserv. 84 235-243. https://doi.org/10.1016/S0006-3207(97)00130-4.

Vilas, A., Gamallo, B., Framil, J., Fernández, J. A., Sanz, K., Lois, M., Toubes, M., Piorno, V. 2014. Guía de visita Parque Nacional Marítimo-Terrestre de las Islas Atlánticas de Galicia. Organismo Autónomo Parques Nacionales.

Wandruszka, R., 2006. Phosphorus retention in calcareous soils and the effect of organic matter on its mobility. Geochem. Trans.

Wild, A., 1993. Soils and the Environment. Cambridge University Press, Cambridge.

Woodmansee, R.G., 1978. Additions and losses of nitrogen in grasslands ecosystems. Bioscience 28 (7), 448-453.

WRB, 2014. World Reference Base for Soil Resources. International soil classification system for naming soils and creating legends for soil maps. World Soil Resources Reports No. 106. FAO, Rome, pp. 1-181.

Zwolicki, A., Zmudczyńska-Skarbek, K.M., Iliszko, L., Stempniewicz, L., 2013. Guano deposition and nutrient enrichment in the vicinity of planktivorous and piscivorous seabird colonies in Spitsbergen. Polar Biol. 36, 363-372. https://doi.org/10.1007/ s00300-012-1265-5. 